\title{
Comparison of Findings from Oblique Radiographs of the Raised Limb with Those of the Weight-bearing Limb for Selected Diseases of the Equine Digit
}

\author{
J. ŠTERC, T. CRHÁKOVÁ \\ University of Veterinary and Pharmaceutical Sciences, Brno \\ Received February 27, 2006 \\ Accepted October 20, 2006
}

\begin{abstract}
Šterc J., T. Crháková: Comparison of Findings from Oblique Radiographs of the Raised Limb with Those of the Weight- bearing Limb for Selected Diseases of the Equine Digit. Acta Vet Brno 2007, 76: 97-103.

In the present study, the radiographic examination of the distal and proximal interphalangeal joints was performed in 43 randomly selected horses. A total of 86 forelimbs were examined. On the forelimbs, dorsolateral-palmaromedial, and dorsomedial-palmarolateral oblique views were performed. The oblique views were performed on raised limbs placed in a navicular block and on weight-bearing limbs placed on a pedestal made at the equine clinic.

In total, 688 dorsolateral-palmaromedial and dorsomedial-palmarolateral views were taken. During the evaluation of the radiographs we focused on the detection of signs of degenerative joint disease of the distal and proximal iterphalangeal joints, and the detection of new bone formation in the phalanx regions, not associated with a disease of the distal or proximal interphalangeal joints.

Based on the radiographic signs visible on these views, we diagnosed 9 cases of degenerative joint disease of the distal intraphalangeal joint, 13 cases of the degenerative joint disease of the proximal intraphalangeal joint and 21 cases of new bone formation in the phalanx regions.

These signs were observed in 253 of 688 oblique views.

Positive radiographic findings of the above-mentioned disorders were shown on 127 oblique views of the raised limb placed in the navicular block and 126 oblique views of the weight-bearing limb placed on the pedestal we made. When 128 oblique views of the weight-bearing limb (placed on the pedestal) were compared with those of the raised limb (in the navicular block), there were different radiographic findings in three cases only. The differences in detection rates of radiographic signs between different type views showed no statistical significance $(p \geq 0.05)$. Therefore we assume that the pedestal we made can be routinely used for the radiographic examination of the distal and proximal interphalangeal joints on DL-PM and DM-PL oblique views, as part of pre-purchase examination or diagnosis of lameness.
\end{abstract}

Radiographic examination, pre-purchase examination, oblique views, $X$-ray findings

Degenerative joint disease (DJD) of distal parts of limbs is a common cause of lameness in horses of different breeds and ages (Gallin a 1982; Trotter et al. 1982). Various agents are involved in the aetiology of the disease; however, they always result in similar characteristic joint changes that may be revealed by careful clinical and radiographic examinations (Trotter et al. 1982; McIlwraith 2001). The radiographic examination plays a unique role in the diagnosis of pathological changes, and is part of the lameness diagnosis. Usually, the radiography follows right after the clinical examination of the affected limb (Kawcak 2001; Stashak 2002). Radiography is an important method of examination of the distal and proximal interphalangeal joints within the pre-purchase examination as it can reveal discrete osteoarthritic changes showing no apparent clinical signs; however, these can induce lameness in the horse in future, and result in a legal dispute between the seller and the buyer (Lauk 2002).

Radiographic examination for DJD of the distal interphalangeal joint in early stages of the disease is based on the detection of periarticular osteophytes on the dorsoproximal border of the distal phalanx, periarticular osteophytes on the dorsal surface of the distal margin of

Address for correspondence:

MVDr. Jan Šterc, PhD

Křídlovická 16

60300 Brno

Czech Republic

Phone: +420608969578

E-mail: stercj@cervus.cz

http://www.vfu.cz/acta-vet/actavet.htm 
the middle phalanx, on the palmar aspect of the distal margin of the middle phalanx and small irregularities and incongruencies of bone surfaces.

With the progression of the disease, subchondral bone lucencies may be visible on the dorsal aspect of the bone surface of the distal phalanx joint, and a narrowed or uneven joint space can be seen on the dorsopalmar view of the distal interpahalangeal joint, and osteophytes on the dorsoproximal border of the navicular bone that should not be confused with enteseophytes (Butler et al. 2000).

In early stages of DJD of the proximal interphalangeal joint, small osteophytes on the dorsoproximal aspect of the middle phalanx are found by radiographic examination. With the progression of the disease, the bone space may become narrowed, and subchondral bone sclerosis and higher numbers of marginal osteophytes may occur. In advanced cases, there may be extensive new bone formation on the proximal aspect of the middle phalanx and on the distal aspect of the proximal phalanx, attempting to bridge the proximal interphalangeal joint and create ankylosis (Butler et al. 2000).

Periarticular osteophytes, formed due to DJD of the distal and proximal interphalangeal joints, should not be confused for new bone formations found by radiography which are not associated with this joint disease (B utler et al. 2000). These findings include:

New bone formation on the dorsal aspect of the proximal phalanx or on the dorsal aspect of the middle phalanx which does not extend to the joint margins and is associated with periostitis caused by external trauma.

Irregular palisading of newly formed bone on the dorsal aspect of the middle phalanx diaphysis. Smoothly outlined newly formed bone can be seen in some cases.

Formation of new bone encircling the phalanges is not associated with the distal and proximal interphalangeal joints.

Enteseophytes in the region of insertion of distal sesamoid ligaments are likely to be formed due to acute or chronic stress of these ligaments.

In the past, a number of studies dealt with radiographic imaging of distal parts of limbs in the horse; they were either anatomical studies or studies describing respective diseases of this region (Trotter at al. 1982; Ellis and Greenwood 1985; Smallwood et al. 1987; Dyson 1991). The above mentioned authors used mostly lateromedial (LM) or dorsopalmar or dosroproximal-palmarodistal (DP-PD) views for imaging the structures of the toe. Other authors (Hertsch and Beerhues 1988; Park et al. 1996) considered oblique views, i.e. dorsomedial-palmarolateral (DM-PL) and dorsolateral-palmaromedial (DL-PM) as essential to reveal certain signs of degenerative joint diseases, particularly small osteophytes on the dorsolateral and dorsomedial aspects of the distal and proximal interphalangeal joints. This corresponds with the opinion of the other authors who recommend the use of oblique views particularly for radiographic examination of distal parts of the forelimbs within the pre-purchase examination of a horse (Lauk 2002; Van Oldruitenborgh-Oosterbaan 2002).

DP-PD, DL-PM and DM-PL views are usually performed on a raised limb placed on a navicular block (Oxpring 1935; Campbell and Lee 1972; Butler et al. 2000). On DP-PD view, the horizontal primary beam is centred $2 \mathrm{~cm}$ proximally above the coronary band in the middle of the dorsal aspect of the toe, and falls onto the film placed behind the examined region. This view is designated as dorsoproximal-palmarodistal "upright pedal" oblique view (Butler et al. 2000). On DL-PM and DM-PL views, the horizontal primary beam is centred at the coronary band in the middle of the lateral or medial aspects of the toe; the X-ray beam and the dorsopalmar axis of the toe usually form an angle of $45^{\circ}$ or $60^{\circ}$ and the beam falls onto the cassette placed behind the examined region (Butler et al. 2000).

A disadvantage of these views is that the assisting personnel must hold the examined limb, 
and thus be exposed to scattered radiation by interactions among the primary beam, examined limb and cassette (Lavin 1999).

The DP-PD view can also be performed on weight-bearing limbs (Campbell and Lee 1972; Butler et al. 2000). For this view, the weight-bearing limb is placed on a pedestal with a nick to fix the cassette behind the toe that the primary X-ray beam and the cassette placed behind were perpendicular. The primary X-ray beam is also centred approximately $2 \mathrm{~cm}$ proximally to the coronary band in the middle of the dorsal aspect of the toe, and falls onto the dorsal aspect in dorsoproximal-palmarodistal direction, at an angle of $85^{\circ}$. This view is designated as dorsoproximal-palmarodistal "high coronary" oblique view (B utler et al. 2000). The fact that the examined limb need not be held by an assistant is an advantage of this view. The assistant restrains the horse by raising the opposite forelimb. Because the distance between the assistant and the source of scattered radiation is greater, the assistant's exposure to radiation is supposed to be lower (Lavin 1999). However, it is not possible to perform DL-PM and DM-PL views on the above described pedestal because the cassette cannot be apposed to the examined region. This could be facilitated by an adequately high pedestal with a slanted back wall, which would allow the apposition of the cassette to the palmaromedial or palmarolateral aspect of the toe corresponding with the inclination of the pastern.

Therefore we decided to make a pedestal that would enable us to conduct the radiographic examination of the distal and proximal interphalangeal joint in oblique views of the weightbearing limb. We assumed that such a pedestal would simplify and speed up the radiography of the joints. The reason is that when a limb is placed on the pedestal, the radiographic examination of the distal and proximal intraphalangeal joints can be performed not only on oblique views, but also on lateromedial and dorsoproximal-palmarodistal views. We also assumed that a limb placed on the pedestal would not have to be held firmly by an assistant and thus unnecessary exposure to scattered radiation would be avoided. When the pedestal was prepared, we had to demonstrate whether the same radiographic sings are revealed on oblique views of a limb placed on the pedestal as on oblique views of a limb placed on a navicular block. Therefore the aim of this study was to demonstrate that the dorsolateral-palmaromedial and dorsomedal-palmarolateral views of the distal and proximal interphalangeal joints of the weight-bearing limb placed on the pedestal we had made would yield the same diagnosis of DJD of the distal and proximal interphalangeal joints and findings of new bone formations on phalanges as the views of the raised limb placed on the navicular block.

\section{Materials and Methods}

We constructed a pedestal with a truncated back wall. The pedestal is depicted in Fig. 1. Due to its design, the pedestal enabled to position the film parallel with the pastern and right behind it, both on DM-PL and DL-PM views, and in LM and DP-PD views (Plate V, VI, VII, Figs. 2 - 5).

For this study, 43 horses were randomly selected, of both sexes, from 3 to 18 years of age. The following breeds were used: 35 warmblood, 5 thoroughbred, 2 coldblood horses and 1 Hutzul. Radiographic examination of the distal and proximal interphalangeal joints of forelimbs of the horses on dorsolateral-palmaromedial and dorsomedialpalmarolateral oblique views was performed.

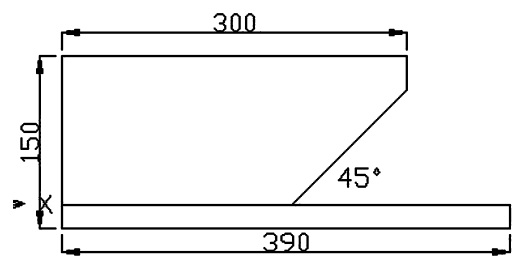

Fig. 1. The drawing of the pedestal constructed for radiological examination of the distal and proximal interphalangeal joints on oblique views of weight-bearing limbs. 
The radiographic examination was performed using a portable X-ray machine Gierth $80 \mathrm{HF}$ (with an output of $15 \mathrm{~mA}$ at $80 \mathrm{kV}$ ), focal distance of $70 \mathrm{~cm}$, and exposure values $0.9 \mathrm{mAs}$ and $65-70 \mathrm{kV}$, without a grid.

The radiographic examination of the forelimbs of the horses was conducted in the following way: each forelimb was placed in the navicular block first so that the DP-PD "upright pedal" oblique view could be performed. Then two DL-PM views and two DM-PL views of the limb were taken. During taking the radiographs, the horizontal primary beam was centred to the coronary edge in the middle of the lateral or medial aspect of the digit and formed an angle of $45^{\circ}$ first and $60^{\circ}$ second with the dorsopalmar axis of the digit. In order to accurately measure the angle of the primary beam, a circular sector template was used. Hereinafter, the views are designated as DL-PM60up, DL-PM45up and DM-PL60up, DM-PL45up.

Then the limb was placed on the pedestal made by ourselves and the horse was immobilized by raising the collateral forelimb. Thus, the limb under examination was fully weight- bearing and positioned suitably for the DP-PD "high coronary" oblique view. Then, two radiographs were made on DL-PM views and two radiographs on DM-PL views of the positioned limb. When taking the radiographs, the primary beam was centred to the coronary edge in the middle of lateral or medial aspect of the digit and it was inclined so that it would fall on the longitudinal (proximodistal) axe of the digit about $85^{\circ}$ aslant, and made an angle of $45^{\circ}$ and then $60^{\circ}$ with the dorsopalmar axis of the digit. For the precise determination of the primary beam angle, a circular sector template was used. Hereinafter, the views are designated as DL-PM60hc, DL- PM45hc and DM-PL60hc, DM-PL45hc. In total, 344 DL-PMup and DM- PLup oblique views and 344 DL-PMhc and DM-PLhc oblique views were taken.

All the radiographs obtained were independently evaluated by each of the two authors of the present study; all the X-ray findings of DJD of the distal interphalangeal joint, DJD of the proximal interphalangeal joint and new bone formations on phalanges not associated with the joint disease were recorded. Subsequently, the radiographs were assessed by an independent scrutineer. The diagnosis of the above-mentioned diseases was confirmed if there was a positive finding of any of the radiographic signs reported by Butler et al. (2000) on one of the oblique views at least.

Based on the findings obtained, all radiographs were compared for congruity as follows:

The radiological findings in radiographs of the toes performed on DL-PM60up with the radiological findings on radiographs of toes performed on DL-PM60hc,

The radiological findings in radiographs of the toes performed on DL-PM45up with the radiological findings in radiographs of the toes performed on DL-PM45hc,

The radiological findings in radiographs of toes performed on DM-PL60up with the radiological findings on radiographs of the toes performed on DM-PL60hc,

The radiological findings in radiographs of the toes performed on DM-PL45up with the radiological findings in radiographs of the toes performed on DM-PL45hc,

The comparison was performed by the test of differences between two relative values $\left(\chi^{2}\right)$.

\section{Results}

When taking DL-PMhc and DM-PLhc views of the distal and proximal interphalangeal joints of the forelimbs in all the 43 horses, it proved possible to perform radiography of the joints in the weight-bearing limb, using the pedestal we made. The pedestal facilitated radiography of the distal and proximal interphalangeal joints not only on DL-PM and DMPL oblique views, but also on LM and DP-PD views. The use of the pedestal was simple and easy. Calm horses allowed their examined limbs to be placed on the pedestal, with the collateral forelimb raised, and remained standing on the pedestal for the whole radiographical examination. Uneasy and nervous horses were examined in the same way and without considerable difficulties after sedation with xylazine or detomidine. It was more efficient to immobilize the horse on the pedestal by raising the other forelimb than by fastening the examined limb in the navicular block.

By evaluating all the 688 radiographs taken, 9 cases of DJD of the distal interphalangeal joint, 13 cases of DJD of the proximal interphalangeal joint and 21 cases of new bone formation on the phalanges were diagnosed. These disorders were diagnosed in 25 horses, and 35 limbs. The diagnosis of the above-mentioned disorders was confirmed if there was a positive finding of any of the radiographic signs reported by Butler et al. (2000) on at least one of the oblique views taken. The positive findings of these radiographic signs were observed in 253 of total 688 oblique views.

By comparing DL-PMhc and DM-PLhc oblique views with corresponding DL-PMup and DM-PLup oblique views, the following was found:

In 8 of 9 cases of DJD of the distal interphalangeal joint, identical signs of the disease were found on DL-PMhc and DM- PLhc oblique views as on the corresponding DL-PMup and 
DM- PLup oblique views. One case of DJD of the distal interphalangeal joint was diagnosed on the basis of finding periarticular osteophyte on the dorsolateral aspect of the distal end of the pastern bone and periarticular osteophyte on the dorsolateral aspect of the proximal end of the pedal bone, visible on DM-PL60up and DM-PL45up oblique views. These radiographic signs, however, were not detected on corresponding DM-PL60hc and DMPL45hc oblique views.

In all the 13 cases of DJD of the proximal interphalangeal joint, on DL-PMhc and DMPLhc oblique views with positive findings, identical radiographic signs of the disease as on the corresponding DL-PMup and DM-PLup oblique views were found.

In 20 of 21 cases of finding the new bone formation on the phalanges, identical radiographic signs of the disease were found on DL-PMhc and DM-PLhc views with positive findings as on the corresponding DL-PMup and DM-PLup oblique views were found. In one case of new bone formation on the phalanges, a small palisade formation of newly formed bone on the dorsomedial aspect of the pastern bone diaphysis was found on the DL-PM45hc oblique view. The radiographic sign, however, was not visible on corresponding DL-PM45up oblique views.

The above mentioned observations imply that by comparing 128 DL-PMhc and DM-PLhc oblique views with the corresponding DL- PMup and DM-PLup oblique views no identical radiographic signs were found in 3 cases. By evaluating the differences in detection rates of radiographic signs in these radiographs it was found that the detection rate differences observed are not significant $(p \geq 0.05)$. Summarized numbers of identical and non-identical positive findings of radiographic signs of the disorders under study on different views are listed in Table 1.

Table 1. Comparison of positive radiological findings from oblique views

\begin{tabular}{|l|c|c|c|c|c|c|}
\hline & \multicolumn{3}{|c|}{$\begin{array}{c}\text { Numbers of oblique views with } \\
\text { positive radiological findings }\end{array}$} & \multicolumn{3}{c|}{$\begin{array}{c}\text { Numbers of consistent } \\
\text { and inconsistent oblique views }\end{array}$} \\
\hline View & $\begin{array}{c}\text { Total number } \\
\text { of positive } \\
\text { radiol. findings }\end{array}$ & $\begin{array}{c}\text { UP } \\
\text { view }\end{array}$ & $\begin{array}{c}\text { HC } \\
\text { view }\end{array}$ & $\begin{array}{c}\text { Consistent } \\
\text { UP-HC }\end{array}$ & $\begin{array}{c}\text { Consistent } \\
\text { in \% }\end{array}$ & $\begin{array}{c}\text { Inconsistent } \\
\text { UP-HC }\end{array}$ \\
\hline DL-PM 60 & 34 & 34 & 34 & 34 & 100.0 & 0 \\
\hline DM-PL 60 & 31 & 31 & 30 & 30 & 96.8 & 1 \\
\hline DL-PM 45 & 30 & 29 & 30 & 29 & 96.7 & 1 \\
\hline DM-PL 45 & 33 & 33 & 32 & 32 & 97.0 & 1 \\
\hline $\begin{array}{l}\text { All oblique } \\
\text { views }\end{array}$ & 128 & 127 & 126 & 125 & 97.7 & 3 \\
\hline
\end{tabular}

\section{Discussion}

It is well known that oblique views enable to reveal some signs of DJD of the distal and proximal interphalangeal joint in horses (Hertsch and Beerhues 1988; Park et al. 1996). The radiographic examination of distal parts of forelimbs on oblique views is supported by some researches mainly as part of pre-purchase horse examination (Lauk 2002; V an Oldriutenborgh-Oosterbaan 2002). The reason is that the views enable to reveal radiographic signs of DJD of the distal and proximal interphalangeal joint that does not necessarily show clinical signs at the time of radiography, but can induce lameness in future. These facts justify the inclusion of oblique views of the distal and proximal interphalangeal joints in the standard radiographic examination of the pre-purchase examination of the horse.

One disadvantage of the inclusion of the oblique views in the standard radiographic prepurchase examination of the horse is the fact that it makes examination more extensive and 
elaborate and the radiographer with assistants receive higher scattered radiation doses during the examination.

This is due to the fact that during the radiographic examination of the distal and proximal interphalangeal joints on the forelimb on DL-PMup and DM-PLup oblique views the limb is placed in the navicular block where it must be immobilized (held) by an assistant (B utler et al. 2000). The manipulation with the limb is difficult in uneasy and nervous horses, and it often requires more time and help of experienced personnel.

Moreover, the assistant holding the limb is close to the source of scattered radiation aimed at the examined part of a limb and the cassette. Therefore, it is assumed that the assistant is exposed to much higher doses of scattered ionizing radiation than during other examinations performed on weight-bearing limbs where the assistant restrains the horse by raising the opposite limb (Lavin 1999).

We tried to eliminate the above negative aspects by constructing and using the pedestal. In this study it was demonstrated that it is technically feasible to perform the radiographic examination of the distal and proximal interphalangeal joints on the weight-bearing limb placed on the pedestal. It was also demonstrated that the handling of the horse subjected to examination that stands on the pedestal is easier. It was demonstrated, that the immobilization of a horse placed on the pedestal by raising the collateral forelimb is easier and more efficient than the immobilization of the limb in the navicular block. The shape of the pedestal also enables to carry out the radiographic examination of the distal interphalangeal joint on LM and DP- PD "high coronary" oblique views.

We also assume that the assistant immobilizing the horse and standing on the pedestal during the radiographic examination on DL-PMhc and DM-PLhc views by raising the collateral forelimb is less exposed to scattered radiation than when the examined limb is placed in the navicular block during the examination on DL-PMup and DM-PLup oblique views. The actual scattered radiation burden of the radiologist and the assistants during the examination of the distal interphalangeal joint will be demonstrated in another study.

Because in the comparison of 128 DL-PMhc and DM-PLhc oblique views with the corresponding DL-PMup and DM-PLup oblique view, different radiographic findings were observed in 3 cases only, and because the difference in radiographic signs detection in the above-mentioned radiograms was not significant, we dare claim that the oblique views of the distal and proximal interphalangeal joints performed on weight-bearing limbs (positioned on the pedestal constructed by ourselves) give the same detection rates as those received in the corresponding oblique views of the raised limb (placed in the navicular block).

Therefore we assume that the pedestal we made can be routinely used for the radiographic examination of the distal and proximal interphalangeal joints on DL-PM and DM-PL oblique views and on LM and DP-PD views, as part of pre-purchase examination or diagnosis of lameness.

\section{Srovnání výtěžnosti šikmých projekcí provedených na zvednuté končetině s výtěžností šikmých projekcí provedených na zatížené končetině při rentgenologické diagnostice vybraných onemocnění prstu u koně}

V naší studii jsme u souboru 43 náhodně vybraných koní provedli rentgenologické vyšetření kopytního a korunkového kloubu. Celkem jsme tedy rentgenologicky vyšetřili 86 hrudních končetin. Vyšetření jsme provedli v šikmých projekcích tj. dorzolaterálně-palmaromediálních a dorzomediálně-palmarolaterálních šikmých projekcích. Šikmé projekce jsme zhotovili na zvednuté končetině umístěné ve střelkovém bloku a na zatížené končetině postavené na námi zkonstruovaném podstavci. V rámci tohoto vyšetření jsme zhotovili celkem 688 dorzolaterálně-palmaromediálních a dorzomediálně-palmarolaterálních šikmých pro- 
jekcí. Při vyhodnocení získaných rentgenogramů jsme se zaměřili na odhalení příznaků degenerativního kloubního onemocnění na kopytním a korunkovém kloubu a na odhalení formací novotvořené kosti na článcích prstů, které nesouvisely s onemocněním kopytního nebo korunkového kloubu. Na základě rentgenologických příznaků viditelných na těchto rentgenogramech jsme diagnostikovali 9 př́ipadů degenerativního kloubního onemocnění kopytního kloubu, 13 př́ípadů degenerativního kloubního onemocnění korunkového kloubu a 21 případů nálezů novotvořené kosti na článcích prstů. Tyto př́iznaky jsme zaznamenali na 253 z celkového počtu 688 zhotovených šikmých projekcí.

Pozitivní nález rentgenologických příznaků výše uvedených postižení byl zachycen na 127 šikmých projekcích provedených na zvednutých končetinách umístěných ve střelkovém bloku a na 126 šikmých projekcích provedených na zatížených končetinách postavených na námi zkonstruovaném podstavci. Při srovnání 128 šikmých projekcí provedených na zatížených končetinách (postavených na námi zkonstruovaném podstavci) se stejnými projekcemi provedenými na zvednutých končetinách (umístěných ve střelkovém bloku) byl zjištěn rozdílný rentgenologicky nález jen ve 3 případech. Vyhodnocením rozdílů $v$ záchytu rentgenologických příznaků na těchto rentgenogramech bylo zjištěno, že tyto rozdíly v záchytu nejsou statisticky významné $(p \geq 0,05)$.

\section{References}

BUTLER JA, COLLES CM, DYSON SJ, KOLD SE, POULOS PW 2000: Foot, Pastern and Fetlock. In: BUTLER JA, COLLES CM, DYSON SJ, KOLD SE, POULOS PW: Clinical Radiology of the Horse. London; Blackwell Science Ltd., pp. 27-130

CAMPBELL JR, LEE R 1972: Radiological Techniques in the diagnosis of navicular disease. Equine Vet J 4: $135-138$

DYSON S 1991: Lameness due to pain associated with the distal interphalangeal joint: 45 cases. Equine Vet J 23: $128-135$

ELLIS DR, GREENWOOD R 1985: Six cases of degenerative joint disease of the proximal interphalangeal joint of young thoroughbreds. Equine Vet J 17: 66-68

GALLINA AM 1982: Bone and Joint Pathology. Equine Med Surg 2: 981

HERTSCH B, BEERHUES U 1988: Der Wendeschmerz als Symptom bei der Lahmheitsuntersuchung des Pferdes - pathomorphologische, röntgenologische und klinische Untersuchungen. Pferdehailkunde 4: 12-22

KAWCAK CHE 2001: Current and future diagnostic means to better characterize osteoarthritis in the horseimaging. AAEP Proceedings 47: 164-170

LAUK HD 2002: Kaufuntersuchung - die ständige Herausforderung. Brauchen wir einen erweiterten Standard? Pferdeheilkunde 18: 212-216

LAVIN LM 1999: Radiation safety. In: LAVIN LM: Radiography in veterinary technology. Philadelphia; W.B. Saunders Company, pp. 21-40.

McILWRAITH CW 2001: Disease processes of synovial membrane, fibrous capsule, ligaments and articular cartilage. AAEP Proceedings 47:142-156

OXPRING GE 1935: The radiology of navicular disease with observations on its pathology. Vet Rec 48:1434-1447

PARK RD, STEYN PF, WRIGLEY RH 1996: Imaging Techniques in the Diagnosis of Equine Joint Disease. In: McILWRAITH CW Joint Disease in the Horse. Philadelphia; W. B. Saunders Company, p. 145.

SMALLWOOD JE, STEVEN MS, HOLLADAY D 1987: Xerographic anatomy of the equine digit and metacarpophalangeal region. Vet Radiol Ultrasound 28: 166-173

STASHAK T S 2002: Lameness. Part I: The Foot, and Part II: The Pastern. In: STASHAK TS: Adams' lameness in horses. Philadelphia; Lippincott Williams and Wilkins, pp. 645-767

TROTTER G, MCILWRAITH CW, NORRDIN RW, TURNER A 1982: Degenerative joint disease with osteochondrosis of the proximal interphalangeal joint in young horses. J Am Vet Med Assoc 180: 1312-1318

VAN OLDRUITENBORGH-OOSTERBAAN MMS 2002: Die Tierärztliche Kaufunterzuchung von Pferden in den Niederlanden. Pferdeheilkunde 18: 243-252 
Plate V

Šterc J. and Crháková T.: Comparison of Findings ... pp. 97-103

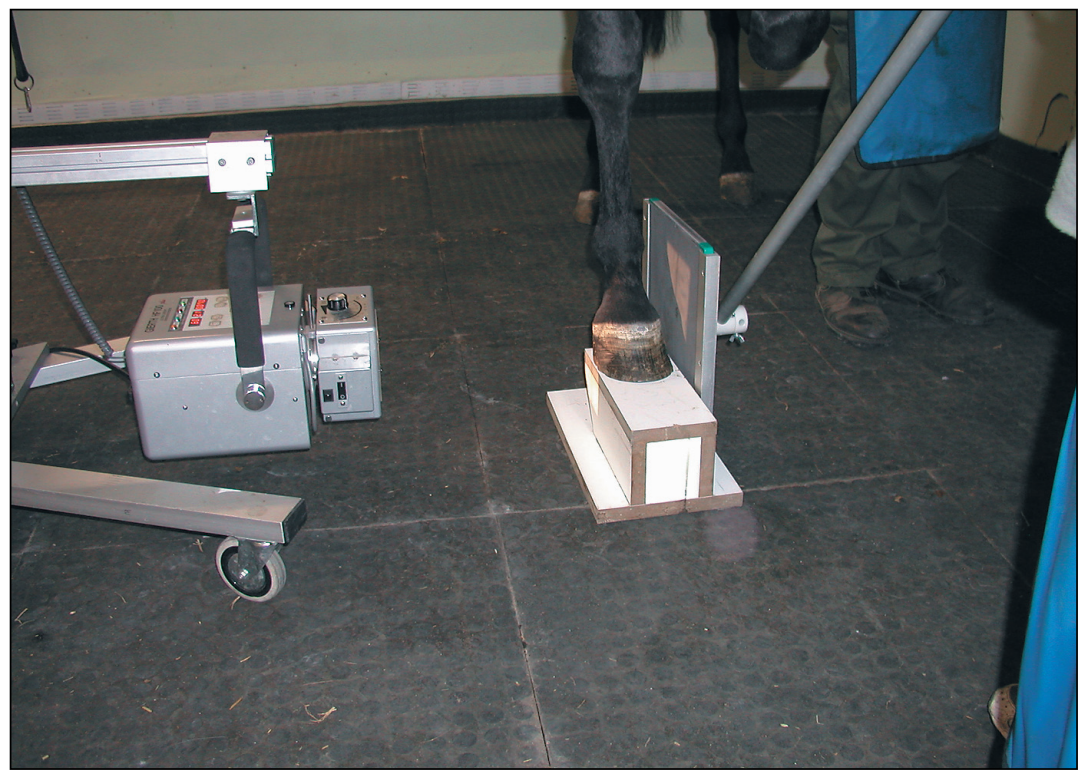

Fig. 2. The use of the pedestal for the lateromedial view of the distal interphalangeal joint

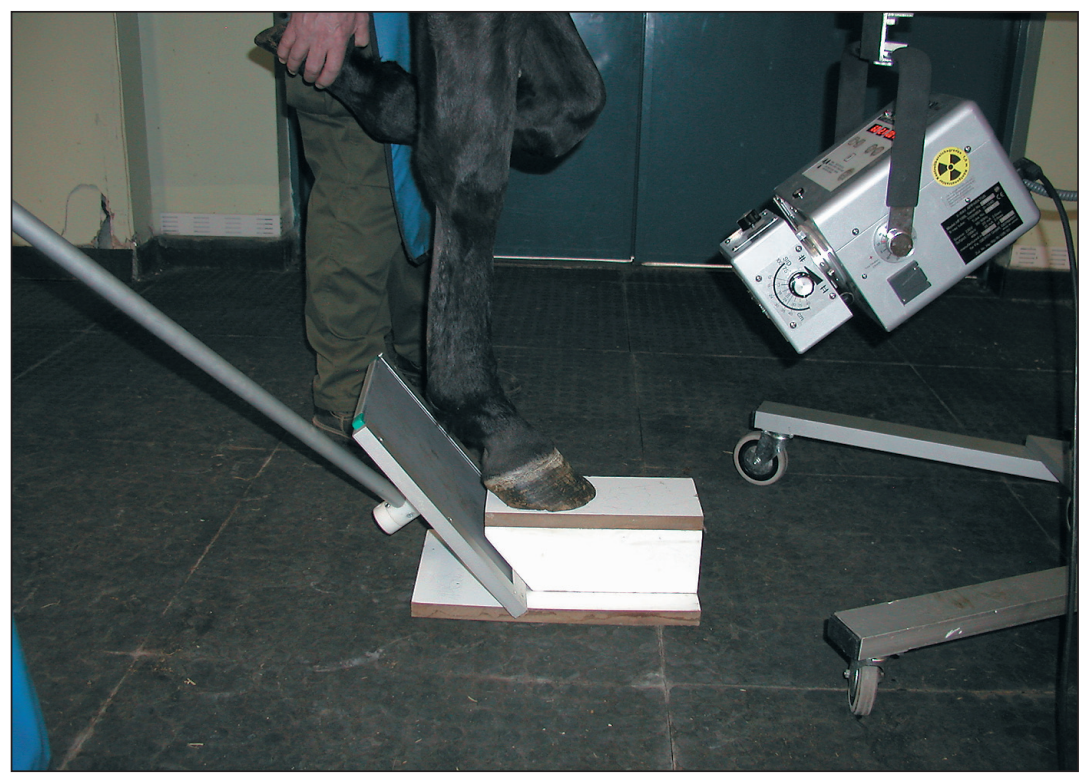

Fig. 3. The use of the pedestal for the dorsoproximal-palmarodistal view of the distal interphalangeal joint 


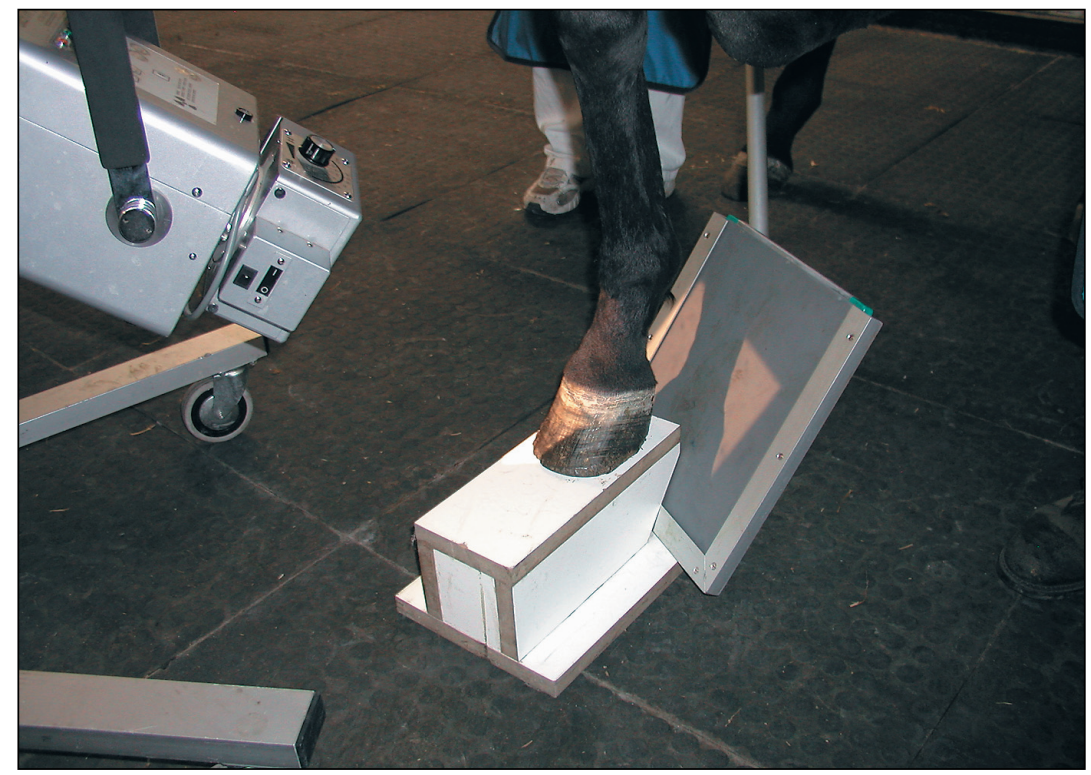

Fig. 4. The use of the pedestal for the dorsolateral-palmaromedial view of the distal interphalangeal joint

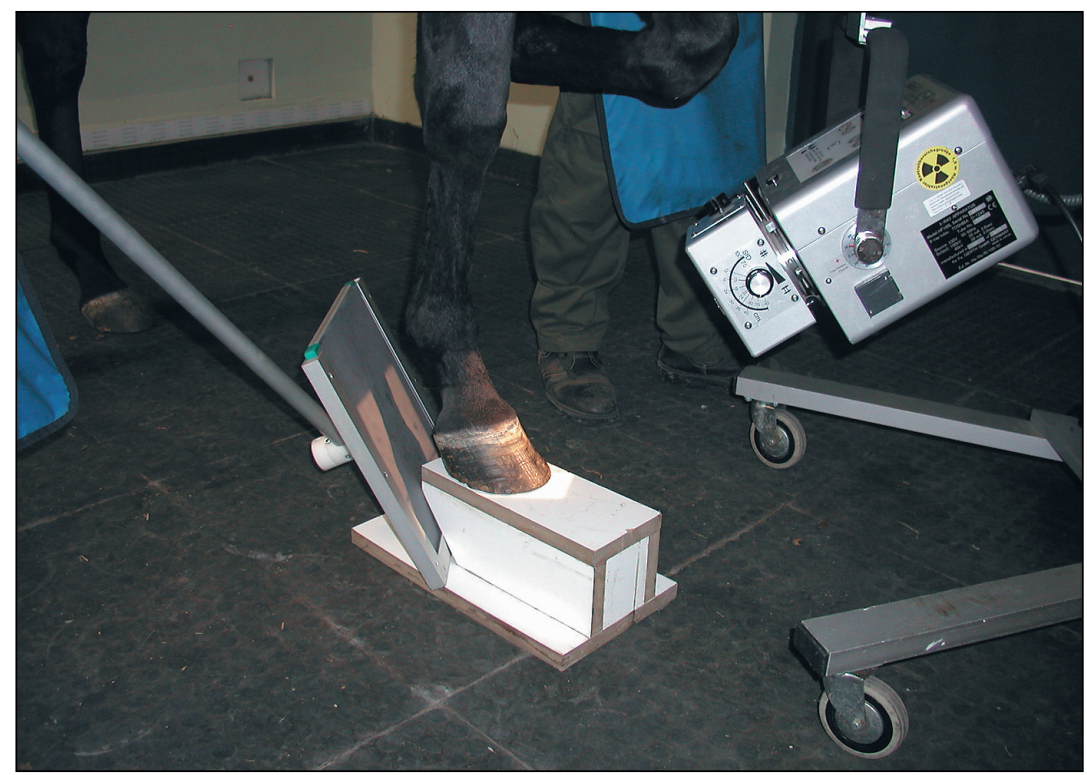

Fig. 5. The use of the pedestal for the dorsomedial-palmarolatral view of the distal interphalangeal joint 


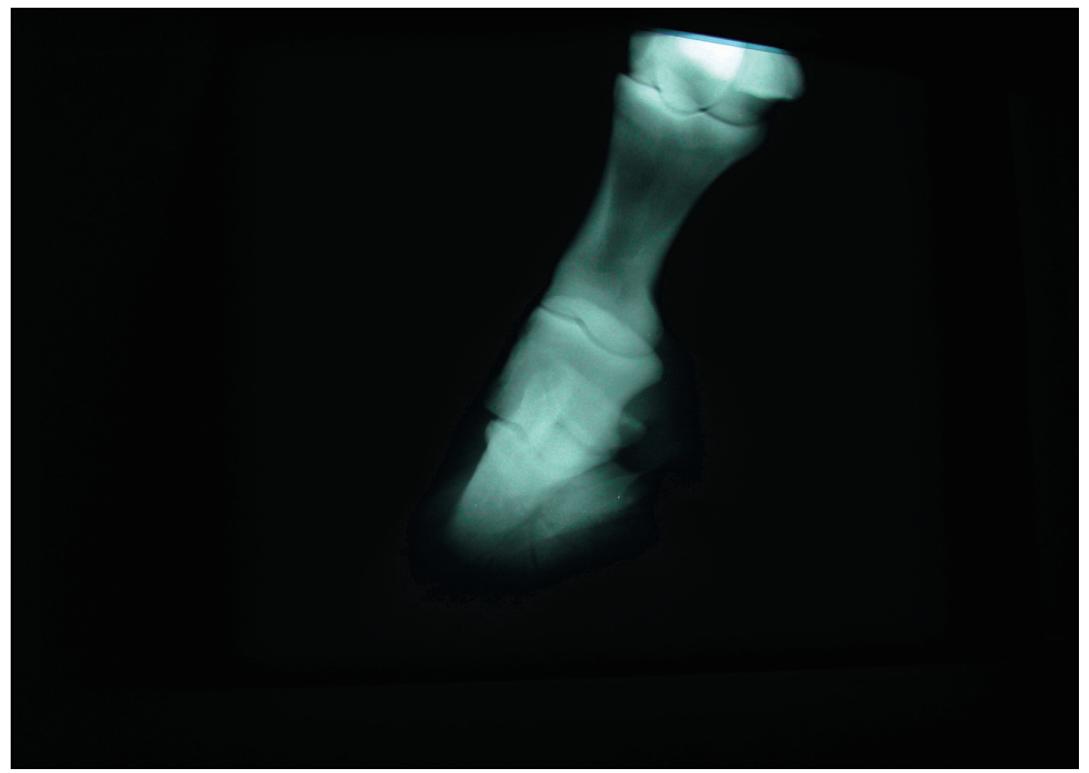

Fig. 6. The dorsolateral-palmaromedial oblique view of the distal and proximal interphalangeal joint 